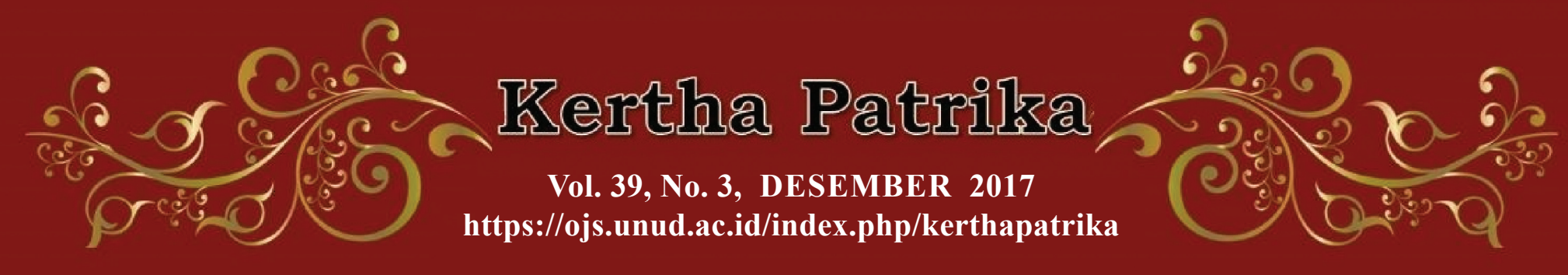

\title{
PERKAWINAN ANTAR NEGARA DI INDONESIA BERDASARKAN HUKUM PERDATA INTERNASIONAL
}

\author{
Oleh :
}

Laurensius Arliman $\mathbf{S}^{\mathbf{1}}$

Sekolah Tinggi Ilmu Hukum Padang

\begin{abstract}
Abstrak
Perkawinan merupakan peristiwa hukum apabila perkawinan tersebut merupakan perkawinan yang sah. Perkembangan ilmu pengetahuan dan teknologi yang begitu pesat membawa pengaruh pada semakin mudahnya terjadi hubungan antar sesama manusia, antar suku bangsa, dan antar Negara dalam segala aspek kehidupan. Salah satu pengaruhnya adalah terjadinya perkawinan campiran antara pasangan berbeda kewarganegaraan, termasuk pada tenaga kerja Indonesia dengan tenaga kerja dari Negara lain. Perkawinan beda kewarganegaraan memang seringkali menimbulkan persoalan, terutama berkaitan dengan proses pencatatan perkawinan yang akan dilangsungkan, apakah di negara asal calon suami atau di negara asal calon istri. Prosedur perkawinan antar Negara menurut hukum perdata internasional menjelaskan bahwa aturan pernikahan terhadap pasangan beda warga negara, dikembalikan pada pasangan masing-masing akan memakai hukum Negara calon suami, atau memakai hukum Negara calon istri. Problem yang muncul dalam prosedur perkawinan campuran beda kewarganegaraan adalah pada tahap mempersiapkan surat keterangan dari pegawai pencatat perkawinan dan pada tahap mempersiapkan surat ataupun dokumen lainnya. Penyelesaian problem yang muncul dalam prosedur perkawinan campuran yang telah dipersiapkan pemerintah adalah memberikan informasi yang jelas dan menyediakan website kepada pasangan yang akan menikah. Kepada oknum-oknum yang nakal, harus diberikan sanksi yang tegas.
\end{abstract}

Kata Kunci: Perkawinan, Antar Negara, Hukum Perdata Internasional.

\section{Abstract}

Marriage is a legal event when the marriage is a legal marriage. The development of science and technology that so rapidly bring the influence on the easier possibility of relations between human beings, between ethnic groups, and between countries in all aspects of life. One of the effects is mixed marriage phenomenon between spouses of different citizenship, including on Indonesian workers with foreign workers. Different nationalities marriage often raises a problem, especially related to the process of marriage registration that will take place, whether in the country of origin of a prospective husband or in the country of origin of a prospective wife. The procedure of mixed nationality marriage according to international civil law explains that marriage rules to different citizen pairs will use either law of the prospective husband's State or law of the prospective wife's State. The problems that arise in a mixed nationality marriage procedure are in the process of preparing a certificate from the marriage officer and at the preparing of the letter or other documents. Completion of the problems that arise in mixed marriages procedures that have prepared government is to provide clear information and website to couples who want to get married. For those who do not comply the rules will be imposed a sanction.

Keywords: Marriage, Inter-State, Private International Law.

DOI: 10.24843/KP.2017.v39.i03.p03

${ }^{1}$ Laurensius Arliman S adalah Dosen pada STIH Padang dan Mahasiswa Doktor Ilmu Hukum Universitas Andalas, Padang, Sumatera Barat. Korespondensi dengan penulis melalui email : laurensiusarliman@gmail.com 
KERTHA PATRIKA

Volume 39, Nomor 3, Desember 2017

\section{PENDAHULUAN}

\subsection{Latar Belakang}

Perkawinan merupakan suatu ikatan yang menunjukkan hubungan antara satu pribadi dengan pribadi yang lain. Sebuah ikatan perkawinan terjadi karena adanya kecocokan pribadi, psikologis dan fisik antara seorang pria dan seorang wanita. ${ }^{2}$ Undang-Undang Nomor 1 Tahun 1974 tentang Perkawinan (UU Perkawinan) merupakan perundang-undangan yang mengatur secara khusus mengenai perkawinan di Indonesia yang berlaku secara efektif sejak tanggal 1 Oktober 1975 yaitu sejak berlakunya Peraturan Pemerintah Nomor 9 Tahun 1975 tentang Pelaksanaan Undang-Undang Nomor 1 Tahun 1974 tentang Perkawinan (PP 7/75). Pengertian dari perkawinan itu sendiri diatur dalam Pasal 1 UU Perkawinan dan dihubungkan dalam Komplikasi Hukum Islam tersebut, menyatakan bahwa Perkawinan ialah ikatan lahir batin antara seorang pria dengan seorang wanita sebagai suami istri dengan tujuan membentuk keluarga (rumah tangga) yang bahagia dan kekal berdasarkan Ketuhanan Yang Maha Esa dan dalam hukum Islam adalah akad yang sangat kuat atau gholiidhan untuk menaati perintah Allah dan melaksanakannya merupakan ibadah. ${ }^{3}$ Dari rumusan perkawinan tersebut jelaslah bahwa perkawinan itu tidak hanya merupakan ikatan lahir batin saja, akan tetapi ikatan kedua-duanya. Pengertian perkawinan menurut UU Perkawinan bukan hanya sekedar sebagai suatu perbuatan hukum saja, akan tetapi juga merupakan suatu perbuatan keagamaan, sehingga oleh karenanya sah atau tidaknya suatu perkawinan digantungkan sepenuhnya pada hukum masing-masing agama dan kepercayaan yang dianut oleh rakyat Indonesia. ${ }^{4}$

Perkawinan merupakan peristiwa hukum, yang akibatnya diatur oleh hukum atau peristiwa yang diberi akibat hukum. Peristiwa oleh Soerjono Soekanto dikatakan sebagai "keadaan" dan "kejadian", maka sikap tindak dalam hukum merupakan peristiwa hukum. Perkawinan merupakan peristiwa hukum apabila perkawinan tersebut merupakan perkawinan yang sah. ${ }^{5}{ }^{6}$ Menurut UU Perkawinan asas yang dimuat adalah asas monogami yang secara otentik diatur didalam Pasal 3 ayat (1). Selain itu Menurut UU Perkawinan mengenai adanya pencatatan perkawinan yang diatur didalam Pasal 2 angka (2), sedangkan pengaturan secara rinci dimuat didalam Pasal 2 sampai dengan Pasal 9 dalam PP 9/75. Menurut Pasal 26 Kitab Undang-Undang Hukum Perdata (KUHPer) dinayatakan bahwa Undang-Undang memandang soal perkawinan hanya dalam hubungan Perdata dan dalam Pasal 81 KUHPer dinyatakan bahwa tidak ada upacara keagamaan yang boleh diselenggarakan, sebelum kedua pihak membuktikan kepada pejabat agama mereka, bahwa perkawinan di hadapan pegawai pencatatan sipil telah berlangsung. Pasal 81 KUHPer ini diperkuat pula oleh Pasal 530 ayat (1) Kitab Undang-Undang Hukum Pidana (KUHP) yang menyatakan "seorang petugas agama yang melakukan upacara perkawinan yang hanya

2 Djaja S Meliala. 2007, Perkembangan Hukum Perdata Tentang Orang dan Hukum Keluarga. Bandung: Nuansa Aulia, h. 71.

3 K.Wantjik Saleh,1980, Hukum Perkawinan Indonesia, Jakarta: Ghalia Indonesia, h. 14.

4 Abdurrahman dan Riduan Syahrani, 1978, Hukum Perkawinan, Bandung: Alumni, h. 9.

5 Soerjono Soekanto dan Sri Mamudji, 1985, Penelitian Hukum Normatif, Suatu Tinjauan Singkat, Jakarta: CV Rajawali, h. 12 .

6 Hilman Hadikusuma, 2007, Hukum Perkawinan Indonesia Menurut Perundangan, Hukum Adat, Hukum Agama, Bandung: Mandar Maju, h. 7. 
Perkawinan Antar Negara di Indonesia Berdasarkan Hukum Perdata Internasional

Laurensius Arliman $S$

dapat dilangsungkan di hadapan pejabat catatan sipil, sebelum dinyatakan kepadanya bahwa pelangsungan di hadapan pejabat itu sudah dilakukan, diancam dengan pidana denda paling banyak Rp. 4.500,- (empat ribu lima ratus rupiah). Kalimat yang hanya dapat dilangsungkan di hadapan pejabat catatan sipil tersebut menunjukan bahwa peraturan ini tidak berlaku bagi mereka yang berlaku hukum Islam, hukum Buddha-Hindu, dan Hukum Adat, yaitu orang-orang yang dahulu disebut pribumi (Inlander) dan Timur Asing (Vreemde Oosterlingen) tertentu di luar orang Cina.

Soerojo Wignjodipoero menyatakan bahwa sistem perkawinan merupakan urusan komunal. Mulai dari mencari pasangan, membuat persetujuan, pertunangan, upacara perkawinan, bahkan sampai kepada akibat-akibat perkawinan. Sesuai dengan kebersamaan sebagai ciri khas komunal, maka rumah tangga (selain urusan yang sangat pribadi) menjadi urusan bersama pula. ${ }^{7}$ Perkawinan sebagai jalan untuk dapat mewujudkan keluarga (rumah tangga) yang bahagia dan kekal berdasarkan Ketuhanan Yang Maha Esa ini dimaksudkan bahwa perkawinan tersebut hendaknya berlangsung seumur hidup dan tidak boleh berakhir begitu saja. Setiap manusia yang melangsungkan perkawinan untuk membangun rumah tangga, pasti semuanya dengan harapan untuk dapat memperoleh kebahagiaan baik dirinya sendiri maupun bagi orang-orang disekitarnya, khususnya keluarga sendiri. Setiap individu manusia di dalam memilih pasangan untuk dinikahi selalu mengimpikan bahwa perkawinan kedepannya kelak adalah membentuk keluarga yang bahagia, sejahtera dan kekal. ${ }^{8}$ Untuk itu suami istri perlu saling membantu dan melengkapi, agar masing-masing dapat mengembangkan kepribadiannya membantu dalam mencapai kesejahteraan spiritual dan materil. Perkawinan dalam arti ikatan adat ialah perkawinan yang mempunyai akibat hukum terhadap hukum adat yang berlaku dalam masyarakat yang bersangkutan. Menurut masyarakat adat Bali, ucapan perkawinan memiliki kata sinonim dengan mesakapan, yang berasal dari kata sakap yang mengandung arti menyatu, dalam hal ini diartikan sebagai menyatunya lingga dengan yoni, dengan sebutan ardhanareswari sebagai kekuatan peleburan dosa. Upacara perkawinan sering juga disebut upacara penganten yang mengandung arti siap sebagai pengganti tanggungjawab orang tua'.

Perkembangan ilmu pengetahuan dan teknologi yang begitu pesat, tanpa mengindahkan lagi batas-batas Negara dan Bangsa. Kemajuan tersebut membawa pengaruh semakin mudah terjadinya hubungan antar sesama manusia, antar suku bangsa dan antar Negara dalam segala aspek kehidupan. Interaksi yang terjadi antara individu yang berbeda suku Bangsa dan Negara dalam berbagai bidang akan melahirkan hubungan-hubungan hukum khususnya dalam Hukum Perdata Internasional (HPI) yang salah satu diantaranya adalah perkawinan campuran. Perkenalan yang membawa pasangan berbeda kewarganegaraan melangsungkan perkawinan campuran

7 Yaswirman, 2011. Hukum Keluaraga-Karakteristik Dan Prospek Doktirn Islam Dan Adat Dalam Masyarakat Matrilineal Minangkabau, Jakarta: Rajawali Press, h. 134. Menurut Yaswirman agaknya yang dimaksud oleh Soerojo adalah karena masingmasing daerah mempunyai adat yang "harus' ditaati oleh warganya, maka perkawinan yang tidak memperhatikan cara-cara adat, secara tradisional tidak bias diterima oleh para pemuka adat, dan tergolong kepada pelanggaran adat. Tetapi Soerojo tidak menjelaskan lebih lanjut bagaimana kalau salah satu pihak dating dari luar yang tidak seadat dengan pihak mana ia akan melansungkan perkawinan, atau seadat tetapi dilakukan diluar wilayah adatnya".

8 Sudarsono, 2005, Hukum Perkawinan Nasional, Jakarta: PT. Rineka Cipta, h. 7.

9 Muhammad Makhfudz, (2012), Berbagai Permasalahan Perkawinan Dalam Masyarakat Ditinjau Dari Ilmu Sosial Dan Hukum, Jurnal Universitas Tama Jagakarsa, h. 6. 
antara lain adalah perkenalan melalui internet, bekas teman kerja atau bisnis, berkenalan saat berlibur, bekas teman sekolah/ kuliah, dan sahabat pena. Perkawinan campuran juga terjadi pada tenaga kerja Indonesia dengan tenaga kerja dari Negara lain. ${ }^{10}$ Pasal 16 Universal Decleration of Human Rights mengatur bahwa setiap manusia mempunyai hak untuk menikah dan berkeluarga tanpa memandang kebangsaan, kewarganegaraan maupun agama, yang penting memiliki rasa suka sama suka. Hak untuk menikah adalah hak yang paling mendasar dan bergantung sepenuhnya pada pilihan setiap ndividu. Pengaturan pasal tersebut menjelaskan bahwa setiap perkawinan tidak di batasi perbedaan kewarganegaraan. ${ }^{11}$

Di Indonesia ada beberapa kasus tentang perkawinan beda kewarganegaraan, dimana kedua belah pihak memiliki kewarganegaraan yang berbeda, Pernikahan beda warga Negara ini seringkali menggoda banyak orang untuk bertanya-tanya. Pertanyaan yang paling umum tentu tentang status kewarnanegaraan kedua orang yang menikah tersebut. Pernikahan seperti ini tentu akan makin menghebohkan manakala melibatkan dua manusia yang sama-sama terkenal, pasangan artis misalnya. Pernikahan beda bangsa terkenal adalah pernikhan para artis Indonesia dengan Warga Negara Asing dari Malaysia, Singapura, Amerika Serikat, Perancis, Jerman, Inggris dan negara lainnya. ${ }^{12}$ Perkawinan campuran ini akan membawa konsekuensi tersendiri yaitu berlakunya peraturan dari masing-masing aturan-aturan hukum yang berlaku terhadap masing-masing pihak yang terlibat. Peraturan perundang-undangan yang mengatur mengenai perkawinan campuran terdapat di dalam UU Perkawinan dalam Pasal 57 yang menyatakan bahwa perkawinan campuran dalam Undang-Undang ini adalah perkawinan antara dua orang yang di Indonesia tunduk pada hukum yang berlainan, karena perbedaan kewarganegaraan dan salah satu pihak berkewarganegaraan Indonesia. ${ }^{13}$ Tujuan dari perkawinan adalah untuk membentuk keluarga yang bahagia dan meneruskan keturunan. Di dalam Pasal 59 angka (1) UU Perkawinan menyatakan bahwa kewarganegaraan yang diperoleh sebagai akibat dari perkawinan atau putusnya perkawinan menentukan hukum yang berlaku, baik mengenai Hukum Publik maupun Hukum Perdata, dari ketentuan tersebut, sangat jelas dalam pekawinan campuran akan menimbulkan konsekuensi yuridis menyangkut kewarganegaraan para pihak.

Perkawinan beda kewarganegaraan memang seringkali menimbulkan kesulitan, terlebih lagi saat proses mencatatkan perkawinan yang akan dilansungkan, apakah di negara asal calon suami atau di negara asal calon isteri. Perkawinan campuran adalah perkawinan antara orang-orang

10 Benyamin, (2015), Fenomena Hukum Campuran Di Indonesia, di dalam: Reminchel, Jaksa Sebagai Pengacara Negara Menurut Undang-Undang Kejaksaan, Jurnal Advokasi, Vol. 7, No. 1, h. 17.

11 C.S.T. Kansil, 1996, Pengantar Ilmu Hukum dan Tata Hukum Indonesia, Jakarta, Balai Pustaka, , h. 474. Salah satu bentuk anti-diskriminasi dari deklarasi ini adalah dalam hal perkawinan Pasal 16 Universal Decleration of Human Rihts 1948 dinyatakan: 1) Orang dewasa baik laki-laki maupun perempuan dengan tidak di batasi oleh kebangsaan, kewarganegaraan atau agama, berhak untuk mencari jodoh dan untuk membentuk keluarga. Mereka mempunyai hak yang sama dalam soal perkawinan, di dalam perkawinan dan di kala perceraian; 2) Perkawinan harus dilakukan hanya dengan cara suka sama suka dari kedua mempelai; 3) Keluarga adalah kesatuan yang sewajarnya serta bersifat pokok dari masyarakat dan berhak mendapat perlindungan dari masyarakat dan negara.

12 Rumrin, (2015), Status Kewarganegraan Artis Bunga Citra Lestari dan Suaminya, Di dalam: Mia Siratni, Proses Penyelesaian Perceraian Di Pengadilan Agama Padang, Jurnal Advokasi, Vol. 7, No. 1, h. 60.

13 Saidus Syahar, 1976, Undang-Undang Perkawinan dan Masalah Pelaksanaannya Ditinjau Dari Segi Hukum Islam, Bandung: Alumni, h. 198 
Perkawinan Antar Negara di Indonesia Berdasarkan Hukum Perdata Internasional

Laurensius Arliman $S$

yang di Indonesia tunduk kepada hukum yang berlainan. Maksud hukum yang berlainan adalah karena perbedaan kewarganegaraan, tempat golongan, dan agama. ${ }^{14}$ Perkawinan campuran didalam UU Perkawinan hanya menekankan pada perkawinan antara Warga Negara Indonesia dengan Warga Negara Asing. Sehubungan dengan adanya perkawinan campuran kewarganegaraan, maka penulis sangat tertarik untuk meneliti dan menganalisa berbagai kasus yang menyebabkan sering timbulnya permasalahan tentang bagaimana proses perkawinan campur di Indonesia.

\subsection{Rumusan Masalah}

Adapun beberapa rumusan masalah yang akan dibahas dalam tulisan ini adalah meliputi:

1. Bagaimanakah memaknai hukum perdata internasional dan hukum kewarganegaraan di Indonesia?

2. Bagaimanakah prosedur perkawinan antar bangsa menurut hukum perdata internasional di Indonesia?

3. Bagaimanakahdinamika dalam proses perkawinan campuran beda kewarganegaraan di Indonesia?

\section{PEMBAHASAN}

\subsection{Memaknai Hukum Perdata Internasional dan Hukum Kewarganegaraan}

Adanya Hukum Perdata Internasional adalah karena ada dalam hubungan hukumnya terdapat unsur asingnya (Foreign Element). Pada umumnya aturan perdata internasional di Indonesia diatur dalam Algemene Bepalingen. Didalam pengertian Hukum Perdata Internasional terdapat 2 (dua) macam aliran, yaitu: 1) Internasionalitas yang mengharuskan agar ada hukum perdata yang berlaku di seluruh dunia atau antar beberapa negara; 2) Nasionalitas, yang di setiap Negara mempunyai Hukum Perdata Internasional masing-masing. Itu memberikan pengertian bahwa HPI ini bukanlah satu hukum yang telah terkodifikasi dan berlaku bagi dunia internasional, namun HPI merupakan hukum yang terkodifikasi di masing masing negara, ${ }^{15}$ dimana hukum tersebut berlaku bagi setiap warga negaranya yang melakukan hubungan internasional.

HPI menurut beberapa ahli hukum antara lain yaitu: ${ }^{16}$ Sudargo Gautama, menyatakan keseluruhan peraturan dan kekhususan hukum yang menunjuk stelsel hukum manakah yang berlaku atau apakah yang merupakan hukum, jika hubungan-hubungan dan peristiwa antara warga-warga Negara pada suatu waktu tertentu memperlihatkan titik pertalian-pertalian dengan stelsel-stelsel dengan kaidah-kaidah hukum 2 (dua) atau lebih Negara yang berbeda dalam lingkungan, kuasa tempat, pribadi dan soal-soal. Van Brakel menyatakan bahwa HPI yaitu hukum nasional yang khusus diperuntukkan bagi perkara-perkara internasional, sedangkan Mochtar

14 Sudargo Gautama, 1987, Pengantar Hukum Perdata Internasional Indonesia, Bandung: Binacipta, h. 250.

6 Sudargo Gautama, Op.cit, h. 6. 
KERTHA PATRIKA

Volume 39, Nomor 3, Desember 2017

Koesoemaatmadja menyatakan HPI adalah keseluruhan kaidah yang mengatur hubungan perdata yang melintasi batas negara. Atau hukum yang mengatur hubungan antar pelaku yang masingmasing tunduk pada hukum perdata negaranya.

Ruang lingkup HPI sendiri terdiri dari: a) HPI = rechtstoepasingrecht ${ }^{17}$, istilah Hukum Perselisihan hanya terbatas pada masalah "hukum yang diperlakukan" (rechtstoepassingrecht), ini merupakan pandangan pertama tentang materi yang termasuk dalam HPI. Pandangan ini misalnya berlaku di Jerman dan Nederland. Materi yang termasuk di bidang HPI sangat terbatas. Tetapi disamping pandangan terbatas ini, masih terdapat lain-lain padangan yang beranggapan bahwa bidang HPI sangat jauh lebih luas; b) HPI = Choice of law + Choice of Jurisdiction ${ }^{18}$, dalam sistem Negara-negara Anglo Saxon dikatakan bahwa HPI ini bukan hanya terdiri dari "conflict of laws", tetapi mencakup pula persoalan-persoalan "conflict of jurisdiction" atau lebih tepat "choice of juriscdiction", yakni persoalan tentang kompetensi wewenang hakim. Jadi bukan saja mengenai hukum manakah yang berlaku, tetapi juga mengenai hakim manakah yang berenang: ${ }^{19} "$ " c) HPI = Choice of law + Choice of Jurisdiction + Condition des Etranges ${ }^{20}$, pandangan ketiga tentang HPI adalah yang lebih luas lagi yaitu seperti dikenal dalam Negara-negara Latin (Italia, Spanyol, Amerika Selatan). Masalah-masalah tentang status orang asing (condition des estrangers, ureemdelingen-statuut) dianggap masalah-masalah pilihan hukum dan pilihan hukum; d) HPI = Choice of law + Choice of Jurisdiction+Condition des Etranges + Nationalite ${ }^{21}$, di samping itu kita lihat sistem yang paling luas, yaitu seperti yang dikenal dalam HPI Perancis. Disamping tiga macam yang disebut tadi sebagai bagian keempat dari HPI ditambahkan masalahmasalah tentang kewarganegaraan (nationalite). ${ }^{22}$

Sedangkan istilah warganegara dalam konteks kosa kata Indonesia merujuk pada atau terjemahan dari kata citizen dalam bahasa inggris atau citoyen dalam bahasa Perancis. Berawal dari konsep citizen inilah kita bisa memberi pemaknaan yang luas mengenai warga Negara. Dengan mengkaji makna citizen nantinya akan dapat diketahui bahwa istilah warganegara sesungguhnya belum cukup untuk mewakili konsep citizen. ${ }^{23}$ Dari pandangan klasik tentang pengertian warganegara, dapat disimpulkan bahwa warganegara atau lebih tepat dengan istilah warga (citizen) menunjuk pada seseorang sebagi anggota dari masyarakat yang dipandang sebagai komunitas politik dan atau komunitas hukum. Penafsiran diatas tidak terlalu salah dengan analisa

17 Ibid, h. 8.

18 Ibid, h. 9.

19 Menurut pandangan Anglo Saxon ini tidak mungkin seorang hakim sampai pada pertanyaan, hukum mana yang kami harus pergunakan, sebelum ia menjawab apakah ia sebagai hakim berwenang untuk mengadili peristiwa ini. Baru setelah itu timbullah pertanyaan kedua, yakni: "kalau saya anggap diri saya berwenang, hukum manakah yang harus saya pakai?". Jadi menurut konsepsi ini selalu dikaitkan pada HPI ini, di samping pertanyaan-pertanyaan choice of law (pilihan hukum) juga pertanyaan-pertanyaan "conflics of jurisdiction, choice of jurisdiction" (pilihan hakim). Jadi ini adalah pandangan kedua tentang HPI, bahwa di samping "choice of law" juga ada "choice of jurisdiction".

20 Ibid, h. 8.

21 Ibid, h. 9.

22 Empat bagian HPI ini dalam textbook-textbook HPI Perancis selalu diperhatikan. Dalam majalah-majalah yang terpenting untuk HPI di Perancis, misalnya "Revue Critique de Droit International Prive" selalu teradapat rubrik-rubrik tertentu mengikuti empat bagian bidang HPI menurut system Perancis ini.

23 Winarmo, 2009, Kewarganegaraan Indonesia Dari Sosiologis Menuju Yuridis, Bandung: Alfabeta, h. 1-2. 
Perkawinan Antar Negara di Indonesia Berdasarkan Hukum Perdata Internasional

Laurensius Arliman $S$

bahwa yang dimaksud warga adalah anggota (member) dari suatu komunitas. ${ }^{24}$ Warganegara sebagai anggota resmi dari masyarakat, sedangkan kewarganegaraan sebagai perangkat karakteristik dari sesorang warganegara.

Karakteristik warganegara yang digambarkan oleh para ahli dan filosof menyiratkan bahwa karakteristik warganegara tidak bisa dilepaskan dari pengaruh sosial politik, latar belakang dan institusi dimana dia hidup. Karakteristik warganegara yang baik menurut Aristoteles adalah adanya keutamaan sipil (civic virtue) dalam dirinya. Menurut Aristoteles ada empat komponen civic virtue yaitu: ${ }^{25}$ 1) Kesederhanaan (temperance) termasuk self-control dan avoidance of extremes; 2) Keadilan (justice); 3) Keberanian atau keteguhan (courage) termasuk patriotism; 4) Kebijaksanaan atau kesopanan (wisdom of prudence) termasuk the capacity for judgement. ${ }^{26}$ Namun dalam perkembangan dunia modern, para ahli berupaya mengembangkan sejumlah karakteristik warganegara yang sejalan dengan dunia modern. Istilah "civic virtue" diartikan sebagai "the willingness of the citizen to set aside privat interest and personal concern for the sake of common good"27. Civic virtue atau kebajikan kewarganegaraan adalah kemauan dari warganegara untuk mengesampingkan kepentingan pribadi atau perhatian individualnya pada kepentingan umum.

Dari sisi hukum, status kewarganegaraan seseorang amat menentukan hak dan kewenangannya selaku warga Negara. Orang yang memiliki status kewarganegaraan akan berbeda dengan seseorang yang tidak berstatus sebagai warga Negara di Negara tersebut ${ }^{28}$. Kewarganegaraan sesorang mengakibatkan orang tersebut memiliki pertalian hukum serta tunduk pada hukum Negara yang bersangkutan. Kewarganegaraan menghasilkan akibat hukum yaitu adanya hak dan kewajiban warga Negara maupun Negara. Hak dan kewajiban warganegara merupakan "isi" atau "aspek material" dari konsep kewarganegaraan itu sendiri. Hak dan kewajiban warganegara pada umumnya dimuatkan dalam konstitusi Negara yang bersangkutan. Akibat hukum yang lain adalah bahwa orang yang sudah memiliki kewarganegaraan tidak jatuh pada kekuasaan atau kewenangan Negara lain. Negara lain juga tidak berhak memperlakukan kaidah-kaidah hukum pada orang yang bukan warga negaranya. ${ }^{29}$ Salah satu kepemilikan yang melekat dalam diri identitas seorang warga adalah hak dan kewajibannya secara resiprokalitas. Artinya ia memiliki hubungan timbal balik dalam komunitasnya yaitu hak dan kewajiban diantara kedua belah pihak. Seorang warga memiliki hak dan kewajiban terhadap komunitasnya, demikian pula sebaliknya komunitas memiliki hak dan kewajiban terhadap anggota. ${ }^{30}$

Pengaturan mengenai kewarganegaraan dan perihal hak dan kewajiban warganegara tertuang pada Pasal 26 sampai dengan Pasal 34 Undang-Undang Dasar 1945 (UUD 1945). Pasal

24 Ibid, h. 9.

25 Ibid, h. 10

26 Warga Negara yang memiliki klasifikasi demikian akan menjadi warga Negara yang baik. Dia akan mampu memerintah secara baik dan juga ia dapat menyatakan warganegara ada yang termasuk good citizen dan bad citizen. Good citizen amat ditentukan dari konstitusi.

27 Ibid, h. 12.

28 J.G. Starke, 2008, Pengantar Hukum Internasional, Cetakan Ketujuh, Jakarta: Sinar Grafika, h. 463.

29 Winarmo, Op cit, h. 54.

30 Ibid, h. 18. 
KERTHA PATRIKA

Volume 39, Nomor 3, Desember 2017

26 UUD 1945 menyatakan tentang siapakah yang termasuk penduduk Indonesia, jadi ini merupakan ketentuan formal Negara Indonesia mengenai warga negaranya. Isi formal kewarganegaraan indonesia ini selanjutnya dituangkan dalam aturan perundang yang lebih lanjut yaitu undang-undang tentang kewarganegaraan. Sedangkan Pasal 27 sampai dengan Pasal 34 berisi tentang ketentuan material mengenai kewarganegaraan Indonesia yaitu tentang hak dan kewajiban warganegara. Isi material kewarganegaraan Indonesia sebagaimana dinyatakan dalam Pasal 27 sampai dengan Pasal 34 UUD 1945 hanya berisi ketentuan-ketentuan dasar atau garis-garis perihal hak dan kewajiban warganegara dalam berbagai bidang nantinya juga termuat dalam pelbagai undang-undang sebagai peraturan pelaksana. ${ }^{31}$ Secara garis besar, hak dan kewajiban selaku warganegara Indonesia sebagaimana telah tertuang didalam Pasal 27 sampai dengan Pasal 34 UUD 1945. 32

\subsection{Prosedur Perkawinan Antar Bangsa Menurut Hukum Perdata Internasional di Indonesia}

Pasal 57 UU Perkawinan menyatakan bahwa hukum perkawinan campuran adalah perkawinan antara dua orang yang berbeda kewarganegaraan. Dari definisi pasal 57 UU Perkawinan ini dapat diuraikan unsur-unsur perkawinan campuran sebagai berikut: ${ }^{33}$ a) perkawinan antara seorang pria dan seorang wanita; b) di Indonesia tunduk pada aturan yang berbeda; c) karena perbedaan kewarganegaraan; d) salah satu pihak berkewarganegaraan Indonesia. Unsur pertama jelas menunjuk kepada asas monogami dalam perkawinan. Unsur kedua menunjukkan kepada perbedaan hukum yang berlaku bagi pria dan wanita yang kawin itu. Tetapi perbedaan itu bukan karena perbedaan agama, suku bangsa, golongan di Indonesia melainkan karena unsur ketiga karena perbedaan kewarganegaraan. Perbedaan kewarganegaraan ini bukan kewarganegaraan asing semuanya, melainkan unsur keempat bahwa salah satu kewarganegaraan itu ialah kewarganegaraan Indonesia. Tegasnya perkawinan campuran menurut UU ini adalah perkawinan antar warganegara Indonesia dan warganegara asing. Karena berlainan kewarganegaraan tentu saja hukum yang berlaku bagi mereka juga berlainan. ${ }^{34}$

Status personil dapat diartikan sebagai peraturan-peraturan hukum mengenai person (seseorang) yaitu kaedah-kaedah hukum yang mengikuti seseorang dimanapun orang itu berada atau kemanapun orang yang bersangkutan pergi, sehingga kaedah-kaedah yang termasuk di dalam status personil mempunyai lingkungan kuasa berlaku tidak terbatas pada wilayah suatu negara tertentu. Di dalam HPI, kita melihat adanya 2 (dua) konsepsi mengenai status personil ini, yakni: Pertama konsepsi yang luas yaitu bahwa yang termasuk di dalam status personil, ialah: a) Dalam bidang hukum Perorangan seperti wewenang untuk mempunyai hak-hak hukum pada umumnya, kemampuan untuk melakukan perbuatan hukum; b) Dalam hukum kekeluargaan, demikian juga

31 Ibid, h. 95.

32 Ibid, h. 96.

33 Noak Sianturi, Perkawinan Campuran, dalam Mia Siratni, Op.cit, h. 61.

34 Atas penjelasan tersebut dapat disimpulkan Perkawinan campuran adalah hubungan perdata yang merupakan bagian dari cakupan HPI. Hal ini dikarenakan perkawinan campuran mengandung unsur asing dimana akan terdapat dua kewarganegaraan yang berbeda. Unsur asing inilah yang menjadikan hubungan tersebut bersifat Internasional sehingga menjadi hubungan Perdata Internasional. 
dalam hal perwalian dan kuasa; c) Pewarisan dalam arti yang seluas-luasnya. Kedua konsepsi yang sempit yaitu bahwa yang termasuk di dalam status personil ialah semua yang termasuk di dalam konsepsi status personil yang luas, kecuali mengenai pewarisan. ${ }^{35}$ Dari kedua konsepsi tersebut baik yang luas maupun yang sempit menempatkan perkawinan adalah termasuk di dalam status personil.

Selanjutnya persoalan yang timbul adalah hukum manakah yang harus diperlukan terhadap status personil sehubungan dengan adanya peristiwa hukum yang termasuk ke dalam hubungan Hukum Perdata Internasional. Sehubungan dengan hal ini maka di dalam Hukum Perdata Internasional kita mengenal adanya 2 (dua) aliran atau prinsip mengenai hukum yang berlaku terhadap status personil ini, yaitu: 1) Prinsip personalitas yang menentukan bahwa status personil dari pada seseorang baik Warga Negara Indonesia maupun warga Negara Asing adalah ditentukan oleh hukum nasionalnya. Jadi dimanapun seseorang itu berada, maka status personil berlaku hukum nasionalnya; 2) Prinsip Teritorialitas yang menentukan bahwa hukum yang berlaku bagi status personilnya seseorang dimana orang tersebut berada atau hukum dimana ia berdomisili. ${ }^{36}$ Prosedur Perkawinan Campuran terdapat dalam masyarakat Indonesia yang hendak melakukan perkawinan campuran (perkawinan beda kewarganegaraan), khususnya bagi Warga Negara Indonesia (WNI) yang akan menikah di Indonesia dengan laki-laki Warga Negara Asing (WNA) ataupun sebaliknya berdasarkan UU Perkawinan. ${ }^{37}$

Perkawinan Campuran yang dilangsungkan di Indonesia dilakukan menurut UndangUndang Perkawinan dan harus memenuhi syarat-syarat perkawinan. Syarat Perkawinan diantaranya: ada persetujuan kedua calon mempelai, izin dari kedua orangtua/wali bagi yang belum berumur 21 tahun, dan sebagaimana yang dinyatakan dalam pasal 6 UU Perkawinan. ${ }^{38}$ Bila semua syarat telah terpenuhi, anda dapat meminta pegawai pencatat perkawinan untuk memberikan Surat Keterangan dari pegawai pencatat perkawinan masing-masing pihak. Surat Keterangan ini berisi keterangan bahwa benar syarat telah terpenuhi dan tidak ada rintangan untuk melangsungkan perkawinan. Bila petugas pencatat perkawinan menolak memberikan surat keterangan, maka anda dapat meminta Pengadilan memberikan Surat Keputusan, yang menyatakan bahwa penolakannya tidak beralasan. Surat Keterangan atau Surat Keputusan Pengganti Keterangan

\footnotetext{
35 Sudargo Gautama, 1985, Aneka Masalah Hukum Perdata Internasional, Bandung: Alumni, h.1-6.

36 Ibid, h. 8.

${ }^{37}$ Noak Sianturi, Op.cit, h. 61.

38 Pasal 6 UU Perkawinan menyatakan: 1) Perkawinan harus didasarkan atas perjanjian kedua calon mempelai; 2)Untuk
} melansungkan perkawinan seorang yang belum mencapai umur 21 (dua puluh satu) tahun harus mendapat izin kedua orang tua; 3 ) Dalam hal seorang dari kedua orang tua telah meninggal dunia atau dalam keadaan tidak mampu menyatakan kehendaknya, maka izin dimaksud ayat (2) pasal ini cukup diperoleh dari orang tua yang mampu menyatakan kehendaknya; 4) Dalam hal kedua orang tua telah meninggal dunia atau dalam keadaan tidak mampu untuk menyatakan kehendaknya, maka izin diperoleh dari wali, orang yang memelihara atau keluarga yang mempunyai hubungan darah dalam garis keturunan lurus ke atas selama mereka masih hidup dan dalam keadaan dapat menyatakan kehendaknya; 5) Dalam hal ada perbedaan pendapat antara orang-orang yang disebut dalam ayat (2), (3), dan (4) pasal ini, atau salah seorang atau lebih di antara mereka tidak menyatakan pendapatnya, maka pengadilan dalam daerah hukum tempat tinggal orang yang akan melansungkan perkawinan atas permintaan orang tersebut dapat memberikan izin setelah lebih dahulu mendengar orang-orang tersebut dalam ayat (2), (3), dan (4) pasal ini; 6) Ketentuan tersebut ayat (1) sampai dengan ayat (5) pasal ini berlaku sepanjang hukum masing-masing agamanya dan kepercayaannya itu dari yang bersangkutan tidak menentukan lain. 
ini berlaku selama enam bulan. Jika selama waktu tersebut, perkawinan belum dilaksanakan, maka Surat Keterangan atau Surat Keputusan tidak mempunyai kekuatan lagi. ${ }^{39}$

Ada beberapa surat lain yang juga harus disiapkan. Untuk calon suami harus meminta calon suami, untuk melengkapi surat-surat dari daerah atau negara asalnya. Untuk dapat menikah di Indonesia, ia juga harus menyerahkan Surat Keterangan yang menyatakan bahwa ia dapat kawin dan akan kawin dengan WNI. Surat Keterangan ini dikeluarkan oleh instansi yang berwenang di negaranya. Selain itu harus pula dilampirkan: 1) Fotokopi Identitas Diri (KTP/paspor); 2) Fotokopi Akta Kelahiran; 3) Surat Keterangan bahwa ia tidak sedang dalam status kawin; 4) Akta Cerai bila sudah pernah kawin; atau Akta Kematian istri bila istri meninggal; 5) Surat-surat tersebut lalu diterjemahkan ke dalam Bahasa Indonesia oleh penterjemah yang disumpah dan kemudian harus dilegalisir oleh Kedutaan Negara WNA tersebut yang ada di Indonesia. Untuk calon istri, sebagai calon istri harus melengkapi diri anda dengan: 1) Fotokopi KTP; 2) Fotokopi Akta Kelahiran; 3) Data orang tua calon mempelai; 4) Surat pengantar dari RT/RW yang menyatakan bahwa anda tidak ada halangan bagi anda untuk melangsungkan perkawinan

Pencatatan perkawinan ini dimaksudkan untuk memperoleh kutipan Akta Perkawinan (kutipan buku nikah) oleh pegawai yang berwenang. Bagi yang beragama Islam, pencatatan dilakukan oleh pegawai Pencatat Nikah atau Pembantu Pegawai Pencatat Nikah Talak Cerai Rujuk. Sedangkan bagi yang Non Islam, pencatatan dilakukan oleh Pegawai Kantor Catatan Sipil. ${ }^{40}$ Kutipan Akta Perkawinan yang telah anda dapatkan, masih harus dilegalisir di Departemen Hukum dan HAM dan Departemen Luar Negeri, serta didaftarkan di Kedutaan negara asal suami. Dengan adanya legalisasi itu, maka perkawinan anda sudah sah dan diterima secara internasional, baik bagi hukum di negara asal suami,maupun menurut hukum di Indonesia

Ada beberapa konsekuensi yang harus anda terima bila anda menikah dengan seorang WNA. Salah satunya yang terpenting yaitu terkait dengan status anak. Berdasarkan UU Kewarganegaraan terbaru, anak yang lahir dari perkawinan seorang wanita WNI dengan pria WNA,maupun anak yang lahir dari perkawinan seorang wanita WNA dengan pria WNI, kini sama-sama telah diakui sebagai warga negara Indonesia.Anak tersebut akan berkewarganegaraan ganda, dan setelah anak berusia 18 tahun atau sudah kawin maka ia harus menentukan pilihannya.

39 Pasal 60 UU Perkawinan menyatakan: 1) Perkawinan campuran tidak dapat dilansungkan sebelum terbukti bahwa syarat-syarat perkawinan yang ditentukan oleh hukum yang berlaku bagi pihak masing-masing telah dipenuhi; 2) Untuk membuktikan bahwa syarat-syarat tersebut dalam ayat (1) telah dipenuhi dank arena itu tidak ada rintangan untuk melansungkan perkawinan campuran, maka oleh mereka yang menurut hukum yang berlaku bagi pihak masing-masing berwenang mencatat perkawina, diberikan suatu keterangan bahwa syarat-syarat telah dipenuhi; 3) Jika pejabat yang bersangkutan menolak untuk memberikan surat keterangan itu, maka atas permintaan yang berkepentingan, pengadilan memberikan keputusan dengan tidak beracara serta tidak boleh dimintakan banding lagi tentang soal apakah penolakan pemberian surat keterangan itu beralasan atau tidak; 4) Jika pengadilan memutuskan bahwa penolakan tidak beralasan keputusan itu menjadi pengganti keterangan yang tersebut ayat (3); 5) Surat keterangan atau keputusan pengganti keterangn tidak mempunyai kekuatan lagi jika perkawinan itu tidak dilansungkan dalam masa 6 (enam) bulan sesudah keterangan itu diberikan.

40 Pasal 61 UU Perkawinan menyatakan: 1) Perkawinan campuran dicatat oleh pegawai pencatat yang berwenang; 2) Barangsiapa melansungkan perkawinan campuran tanpa memperlihatkan lebih dahulu kepada pegawai pencatat yang berwenang surat keterangan atau keputusan pengganti keterangan yang disebut dalam 60 ayat (4) Undang-undang ini dihukum dengan hukuman kurungan selama-lamanya 1 (satu) bulan; 3) Pegawai pencatat perkawinan yang mencatat perkawinan sedangkan ia mengetahui bahwa keterangan atau keputusan pengganti keterangan tidak ada, dihukum dengan hukuman kurungan selama-lamanya 3 (tiga) bulan dan dihukum jabatan. 
Pernyataan untuk memilih tersebut harus disampaikan paling lambat 3 (tiga) tahun setelah anak berusia 18 tahun atau setelah kawin. Jadi bersiaplah untuk mengurus prosedural pemilihan kewarganegaraan anak selanjutnya. Bagi perkawinan campuran yang dilangsungkan di luar Indonesia, harus didaftarkan di kantor Catatan Sipil paling lambat 1 (satu) tahun setelah yang bersangkutan kembali ke Indonesia. Bila tidak, maka perkawinan anda belum diakui oleh hukum kita. Surat bukti perkawinan itu didaftarkan di Kantor Pencatatan Perkawinan tempat tinggal anda di Indonesia ini sesuai dengan ketentuan Pasal 56 UU Perkawinan. ${ }^{41}$

Perkawinan campuran ini akan membawa konsekuensi tersendiri yaitu berlakunya peraturan dari masing-masing stelsel hukum yang berlaku terhadap masing-masing pihak yang terlibat. Peraturan perundang-undangan yang mengatur mengenai perkawinan campuran terdapat dalam Pasal 57 UU Perkawinan yang menyatakan sebagai berikut, bahwa yang dimaksud perkawinan campuran dalam Undang-Undang ini adalah perkawinan antara dua orang yang di Indonesia tunduk pada hukum yang berlainan, ${ }^{42}$ karena perbedaan kewarganegaraan dan salah satu pihak berkewarganegaraan Indonesia. ${ }^{43}$ Sedangkan dilain pihak kita mengenal adanya tempat kediaman atau tempat tinggal seseorang, dimana hal yang terakhir ini merupakan faktafakta yang sama sekali tidak dipengaruhi oleh hukum. Akan tetapi tempat tinggalnya seseorang itu berhubungan erat dengan domisili sebab tempat tinggalnya seseorang kadang-kadang dipakai sebagai dasar untuk menentukan domisili orang yang bersangkutan. Didalam HPI yang dipentingkan ialah domisili seseorang di dalam suatu negara, artinya di negara manakah seseorang mempunyai domisili sehingga dengan demikian dapat ditentukan hukum yang berlaku baginya, misalnya hukum dimana ia berdomisili.

Sehubungan dengan hal tersebut maka kita melihat pengertian domisili yang terdapat di dalam stelsel hukum tertentu yaktu hukum Inggris yang merupakan konsep domisili yang paling unik, dimana domisili menurut hukum Inggris dapat dibagi menjadi 3 (tiga) bagian, yaitu ${ }^{44}$ : 1) Domicilie Of Origin, yaitu tempat tinggal yang diperoleh karena kelahiran, lembaga ini lebih condong kepada paham kewarganegaraan; 2) Domicilie Of Choise, yaitu domisili yang dipilih dengan memperlihatkan bahwa orang yang bersangkutan mempunyai suatu hasrat untuk terus menetap di negara yang baru dipilihnya; 3) Domicilie by Operation Of law, yaitu domisili bagi anak-anak yang belum dewasa, perempuan-perempuan dalam perkawinan dan mereka yang ditaruh di bawah perwalian.

${ }^{41}$ Dengan banyaknya perkawinan campuran di Indonesia sudah seharusnya perlindungan hukum dalam perkawinan campuran ini diakomodir dengan baik dalam perundang-undangan Indonesia. Maka seiring dengan perkembangannya, barulah pada 11 Juli 2006 DPR mengesahkan Undang-Undang Kewarganegaraan baru yaitu Undang-Undang Nomor 12 Tahun 2006 tentang Kewarganegaraan. Secara garis besar Undang-undang baru ini sudah memberikan pencerahan baru dalam mengatasi persoalanpersoalan yang lahir dari perkawinan campuran karena memperbolehkan dwi kewarganegaraan terbatas.

42 Dalam hubungannya dengan pengertian domisili, maka corak utama yang terdapat dalam konsepsi domisili yang dikenal dimana-mana dan pengertian ini adalah sama di dalam setiap stelsel hukum, dimana dengan istilah domisili diartikan yaitu: Negara yang menurut hukum sebagai pusa dari kehidupan seseorang ini tidak dinilai secara sama, artinya berbagai cara yang berbeda digunakan untuk menentukan tempat dimanakah merupakan tempat pusat kehidupan itu. Domisili adalah merupakan pusat kehidupan seseorang yang ditentukan oleh ketentuan-ketentuan hukum.

43 Saidus Syahar, Op.cit, h. 34.

${ }^{44}$ Ibid, h. 301-307. 
Dari kedua prinsip yang menentukan hukum yang berlaku bagi status personil masih terdapat adanya negara-negara yang menganut kombinasi atau campuran antara kedua prinsip tersebut di atas. Adapun kombinasi tersebut sebagai berikut: a) Kombinasi menurut sistem Rusia, yaitu untuk orang-orang asing yang terdapat di dalam negeri diberlakukan prinsip domisili, sedangkan untuk Warga Negara yang bersangkutan yang berada di luar negeri diberlakukan prinsip personalitas tanpa memperhatikan sama sekali bagaimana pendirian dari negara dimana Warga Negara tersebut berdomisili; b) Kombinasi dalam sistem hukum Swiss, yaitu untuk orang-orang asing yang berada di luar negara Swiss diberlakukan Hukum Perdata Swiss, sedangkan kepada Warga Negara Swiss yang berada di luar negeri diberlakukan hukum dimana mereka berdomisili. Akan tetapi apabila hukum dari negara dimana mereka berdomisili menganut asas personalitas maka yang berlaku adalah Hukum Perdata Swiss. Jadi sistem campuran ini terjadi apabila Warga Negara Swiss itu berdomisili pada negara-negara yang menganut asas personalitas, sedangkan apabila Warga Negara Swiss yang berdomisili di negara-negara yang menganut prinsip teritorialitas, maka tidak akan terjadi kombinasi antara kedua prinsip tersebut, jika kita lihat lebih lanjut maka negara-negara yang menganut sistem kombinasi atau campuran ini pada dasarnya didorong oleh hasrat yang dinamakan "Juristischem Chauvinismus" yaitu hasrat untuk mengutamakan hukum negara sendiri dianggap yang paling baik. ${ }^{45}$

Selanjutnya diantara prinsip-prinsip yang ada dan berlaku tersebut maka prinsip yang dianut di Indonesia yang mana akan dipakai. Untuk mengetahui hal tersebut maka kita tidak dapat terlepas dari Pasal 16 AB. Adapun Pasal 16 AB menentukan bahwa: bagi Penduduk Hindia Belanda (sekarang Warga Negara Indonesia),peraturan-peraturan perundang-undangan yang mengenai status dan wewenang seseorang tetap berlaku terhadap mereka apabila mereka berada di luar negeri. Pasal ini berlaku sesuai dengan status personil yang mencakup. ${ }^{46}$ a) Hukum perseorangan termasuk hukum keluarga dan hukum perkawinan dan b) Peraturan-peraturan mengenai benda benda yang tidak tetap.

\subsection{Dinamika Dalam Proses Perkawinan Campuran Beda Kewarganegaraan di Indonesia}

Dinamika yang muncul akibat perkawinan campuran beda kewarganegaraan ini lebih terletak pada kurangnya informasi kepada pasangan yang mau melakukan perkawinan beda kewarganegaraan. Prosedur Perkawinan Campuran terdapat dalam masyarakat Indonesia yang hendak melakukan perkawinan campuran (perkawinan beda kewarganegaraan) diatur di dalam UU Perkawinan. Problem yang muncul akibat perkawinan campuran beda kewarganegaraan ini terjadi karena kurang adanya penyuluhan atau sosialisasi yang diberikan pemerintah kepada setiap warganegara Indonesia. Akibat minimnya informasi aturan hukum ini menyebabkan pasangan yang ingin menikah mengalami kendala-kendala dalam menyiapkan data ataupun dokumen yang dipersiapkan dalam pernikahan mereka.

\footnotetext{
45 Ibid, h. 83-87.

46 Sunaryati Hartono, 1976, Pokok-Pokok Hukum Perdata Internasional, Bandung: Alumni, h. 12.
} 
Perkawinan Antar Negara di Indonesia Berdasarkan Hukum Perdata Internasional

Laurensius Arliman $S$

Data-data dokumen tersebut akan diuraikan oleh penulis sebagai berikut: 1) Surat Keterangan dari Pegawai Pencatat Perkawinan, kurangnya kordinasi yang baik antara pasangan yang menikah dengan Pegawai Pencatat Perkawinan dalam membuat surat keterangan perkawinan pasangan tersebut. Hal itu terjadi karena minimnya informasi yang disediakan pemerintah apabila terjadi pernikahan beda warganegara; 2) Surat-surat yang harus dipersiapkan, untuk calon suami harus meminta calon suami, untuk melengkapi surat-surat dari daerah atau negara asalnya. Untuk dapat menikah di Indonesia, ia juga harus menyerahkan Surat Keterangan yang menyatakan bahwa ia dapat kawin dan akan kawin dengan WNI. Surat Keterangan ini dikeluarkan oleh instansi yang berwenang di negaranya. Selain itu harus pula dilampirkan syarat lainnya. Calon suami terkadang belum menyiapkan hal tersebut karena minimnya informasi yang didapatnya; 3) Serupa dengan calon suami, untuk calon istri, sebagai calon istri harus melengkapi diri anda dengan, fotokopi KTP, fotokopi Akta Kelahiran, data orang tua calon mempelai, surat pengantar dari RT/RW yang menyatakan bahwa anda tidak ada halangan bagi anda untuk melangsungkan perkawinan. Setelah ini dipersiapkan calon istri, ternyata suami masih terkendala dengan persyaratan diatas, sehingga menyebabkan pernikahan belum bisa dilaksanakan.

Penyelesaian yang telah dilakukan pemerintah antara lain telah melakukan pemberian penyebaran-penyebaran informasi terkait syarat-syarat yang harus dilengkapi oleh pasangan beda kewarganegaraan, dimana salah satu pasangannya adalah Warga Negara Indonesia, dan pasangannya adalah Warga Negara Asing. Berdasarkan uraian pada bagian permasalah diatas, adapun solusi yang telah dilakukan oleh pemerintah republik Indonesia adalah: 1) Dalam Tahap Surat Keterangan dari Pegawai Pencatat Perkawinan melakukan: a) Pemerintah telah menyebarkan informasi-informasi tentang surat keterangan tersebut; b) Pemerintah menyiapakan website di internet, pasangan tinggal mengakses link website tersebut; c) Terhadap opnum-opnum Pegawai Pencatat Perkawinan yang nakal, pemerintah akan memberikan sanksi yang tegas; dan 2) Dalam tahap mempersiapkan surat-surat untuk melansungkan pernikahan, adapun solusi yang telah dilakukan oleh pemerintah Republilk Indonesia adalah: a) Senada dengan yang diatas, Pemerintah dan instansi yang terkait telah menyebarkan informasi-informasi; b) Pemerintah juga menyiapkan website di internet, pasangan tinggal mengakses link website tersebut, dan mengikuti data-data yang harus dipersiapkan dalam link informasi tersebut.

Selain itu di dalam melakukan perkawinan maka harus menaati asas-asas perkawinan yang ada $^{47}$, antara lain dapat penulis jabarkan sebagai berikut: Pertama. Asas-asas perkawinan menurut KUHPerdata adalah:48 a) Asas monogami. Asas ini bersifat absolut/mutlak, tidak dapat dilanggar; b) Perkawinan adalah perkawinan perdata sehingga harus dilakukan di depan pegawai catatan sipil; c) Perkawinan merupakan persetujuan antara seorang laki-laki dan seorang perempuan di bidang hukum keluarga; d) Supaya perkawinan sah maka harus memenuhi syaratsyarat yang ditentukan undang-undang; e) Perkawinan mempunyai akibat terhadap hak dan

${ }^{47}$ Dalam ikatan perkawinan sebagai salah satu bentuk perjanjian (suci) antara seorang pria dengan wanita, yang mempunyai segi-segi perdata.

48 Nasrul, 2015, Perkawinan Menurut Hukum Perdata dan Lainnya, di dalam Mia Siratni, Op-cit, h. 61. 
kewajiban suami dan isteri; f) Perkawinan menyebabkan pertalian darah; dan g) Perkawinan mempunyai akibat di bidang kekayaan suami dan isteri itu; Kedua, Asas-asas perkawinan menurut UU Perkawinan adalah: a) Asas Kesepakatan (Bab II Pasal 6 ayat (1) UU Perkawinan), yaitu harus ada kata sepakat antara calon suami dan isteri; b) Asas monogami (Pasal 3 ayat (1) UU Perkawinan). Pada asasnya, seorang pria hanya boleh memiliki satu isteri dan seorang wanita hanya boleh memiliki satu suami, namun ada perkecualian (Pasal 3 ayat (2) UU Perkawinan dengan syarat-syarat yang diatur dalam Pasal 4-5; c) Perkawinan bukan semata ikatan lahiriah melainkan juga batiniah; d) Supaya sah perkawinan harus memenuhi syarat yang ditentukan undang-undang (Pasal 2 UU Perkawinan); e) Perkawinan mempunyai akibat terhadap pribadi suami dan istri; f) Perkawinan mempunyai akibat terhadap anak/keturunan dari perkawinan tersebut; dan g) Perkawinan mempunyai akibat terhadap harta suami dan istri tersebut.

Ketiga adalah, menurut agama Islam asas-asas dalam perkawinan berlaku beberapa asas di antaranya: ${ }^{49}$ a).Asas kesukarelaan, merupakan asas terpenting perkawinan Islam. Kesukarelaan itu tidak hanya harus terdapat antara kedua calon suami istri, tetapi juga antara kedua orang tua kedua belah pihak. Kesukarelaan orang tua yang menjadi wali seorang wanita, merupakan sendi asasi perkawinan Islam. Dalam berbagai hadis nabi, asas ini dinyatakan dengan tegas; b) Asas persetujuan, kedua belah pihak merupakan konsekuensi logis asas pertama tadi. Ini berarti bahwa tidak boleh ada paksaan dalam melangsungkan perkawinan. Persetujuan seorang gadis untuk dinikahkan dengan seorang pemuda, misalnya harus diminta lebih dahulu oleh wali atau orang tuanya. Menurut sunnah nabi, persetujuan itu dapat disimpulkan dari diamnya gadis tersebut. Dari berbagai sunnah dapat diketahui bahwa perkawinan yang dilangsungkan tanpa persetujuan kedua belah pihak, dapat dibatalkan oleh pengadilan; c) Asas kebebasan memilih pasangan, disebutkan dalam sunnah nabi. Diceritakan oleh Ibnu Abbas bahwa pada suatu ketika seorang gadis bernama Jariyah menghadap Rasulullah dan menyatakan bahwa ia telah dikawinkan oleh ayahnya dengan seseorang yang tidak disukainya. Setelah mendengarkan pengaduan itu, nabi menegaskan bahwa ia (Jariyah) dapat memilih untuk meneruskan perkawinan dengan orang yang tidak disukainya itu atau meminta pasangan dan kawin dengan orang lain yang disukainya; d) Asas kemitraan suami istri, dengan tugas dan fungsi yang berbeda karena perbedaan kodrat (sifat, asal, pembawaan) disebut dalam Alquran surat Al-Nisa' (4) ayat 34 dan surat Al-Baqarah (2) ayat 187. Kemitraan ini menyebabkan kedudukan suami istri dalam beberapa hal sama, dalam hal yang lain berbeda : suami menjadi kepala keluarga, istri menjadi kepala dan penanggung jawab pengaturan rumah tangga; e) Asas untuk selama-lamanya, menunjukkan bahwa perkawinan dilaksanakan untuk melangsungkan keturunan dan membina cinta serta kasih sayang selama hidup (QS Al-Rum (30):21). Karena asas ini pula maka perkawinan mut'ah yakni perkawinan sementara untuk bersenang-senang selama waktu tertentu saja, seperti yang terdapat dalam masyarakat Arab Jahiliyah dan beberapa waktu setelah Islam, dilarang oleh Nabi Muhammad; f) Asas monogami terbuka, disimpulkan dari Alquran surat Al-Nisa' (4) ayat 3 jo ayat 129. Di dalam ayat 3 dinyatakan bahwa seorang pria Muslim dibolehkan atau boleh beristri

49 Daud Ali, 2005, Hukum Islam, Jakarta: Grafindo Persada, h. 139-140. 
lebih dari seorang, asal memenuhi beberapa syarat tertentu, diantaranya adalah syarat mampu berlaku adil terhadap semua wanita yang menjadi istrinya. Dalam ayat 129 surat yang sama Allah menyatakan bahwa manusia tidak mungkin berlaku adil terhadap istri-istrinya walaupun ia ingin berbuat demikian. Oleh karena ketidakmungkinan berlaku adil terhadap istri-istri itu maka Allah menegaskan bahwa seorang laki-laki lebih baik kawin dengan seorang wanita saja. Ini berarti bahwa beristri lebih dari seorang merupakan jalan darurat yang boleh dilalui oleh lakilaki Muslim kalau terjadi bahaya, antara lain, untuk menyelamatkan dirinya dari berbuat dosa, kalau istrinya misalnya tidak mampu memenuhi kewajibannya sebagai istri.

\section{PENUTUP}

\subsection{Kesimpulan}

Adapun beberapa kesimpulan yang dapat ditarik pada tulisan ini meliputi:

a. Prosedur perkawinan antar negara menurut Hukum Perdata Internasional menjelaskan bahwa aturan pernikahan terhadap pasangan beda warganegara, dikembalikan pada pasangan masingmasing akan memakai hukum Negara calon suami, atau memakai hukum Negara calon istri;

b. Permasalahan yang muncul dalam prosedur perkawinan campuran beda kewarganegaraan adalah pada tahap mempersiapkan surat keterangan dari pegawai pencatat perkawinan dan pada tahap mempersiapkan surat ataupun dokumen lainnya;

c. Penyelesaian problem yang muncul dalam prosedur perkawinan campuran yang telah disiapkan pemerintah adalah memberikan informasi yang jelas kepada pasangan yang ingin menikah, menyediakan website yang dibutuhkan pasangan beda warga negara yang ingin menikah, serta pemberian sanksi terhadap oknum-oknum yang dianggap nakal.

\subsection{Saran}

Adapun saran yang bisa penulis berikan pada tulisan ini antara lain meliputi:

a. Bagi pasangan yang akan melakukan perkawinan beda warganegara agar mencari informasi yang jelas dalam mempersiapkan dokumen yang dibutuhkan dalam melangsungkan perkawinan nantinya;

b. Pemerintah harus memberikan informasi yang jelas, dan menyediakan informasi yang dibutuhkan pasangan beda warganegara;

c. Terhadap oknum-oknum pegawai pemerintahan yang nakal harus diberikan peringatan dan sanksi yang tegas;

d. Pemerintah harus membuat produk hukum yang mengatur secara rinci terkait perkawinan campuran beda warganegara. 


\section{DAFTAR PUSTAKA}

\section{A. Buku}

Abdurrahman Dan Syahrani, Riduan, 1978, Hukum Perkawinan, Alumni Bandung, Bandung. Ali, Daud, 2005, Hukum Islam, Jakarta: Grafindo Persada.

Gautama, Sudargo, 1987, Pengantar Hukum Perdata Internasional Indonesia, Bandung: Binacipta. , 1985, Aneka Masalah Hukum Perdata Internasional, Bandung: Alumni.

Hadikusuma, Hilman, 2007, Hukum Perkawinan Indonesia Menurut Perundangan, Hukum Adat, Hukum Agama, Bandung: Mandar Maju.

Hartono, Sunaryati, 1976, Pokok-Pokok Hukum Perdata Internasional, Bandung: Alumni.

Kansil, C.S.T. 1996, Pengantar Ilmu Hukum Dan Tata Hukum Indonesia, Jakarta, Balai Pustaka.

Meliala. Djaja S, 2007, Perkembangan Hukum Perdata Tentang Orang Dan Hukum Keluarga. Bandung: Nuansa Aulia.

Oktarina, Neneng, 2013, Hukum Perdata Internasional, Buku Ajar, Padang: Universitas Andalas.

Saleh, K.Wantjik, 1980, Hukum Perkawinan Indonesia, Ghalia Indonesia, Jakarta.

Soekanto, Soerjono Dan Mamudji, Sri, 1985, Penelitian Hukum Normatif, Suatu Tinjauan Singkat, Jakarta: CV Rajawali.

Starke, J.G. 2008, Pengantar Hukum Internasional, Cetakan Ketujuh, Jakarta: Sinar Grafika.

Sudarsono, 2005, Hukum Perkawinan Nasional, Jakarta: PT. Rineka Cipta.

Syahar, Saidus, 1976, Undang-Undang Perkawinan Dan Masalah Pelaksanaannya Ditinjau Dari Segi Hukum Islam, Bandung: Alumni.

Winarmo, 2009, Kewarganegaraan Indonesia Dari Sosiologis Menuju Yuridis, Bandung: Alfabeta.

Yaswirman, 2011. Hukum Keluaraga-Karakteristik Dan Prospek Doktirn Islam Dan Adat Dalam Masyarakat Matrilineal Minangkabau, Jakarta: Rajawali Press.

\section{B. Jurnal}

Makhfudz, Muhammad, (2012), Berbagai Permasalahan Perkawinan Dalam Masyarakat Ditinjau Dari Ilmu Sosial Dan Hukum, Jurnal Universitas Tama Jagakarsa. 
Reminchel, (2015), Jaksa Sebagai Pengacara Negara Menurut Undang-Undang Kejaksaan, Jurnal Advokasi, Vol. 7, No. 1.

Siratni, Mia, (2015), Proses Penyelesaian Perceraian Di Pengadilan Agama Padang, Jurnal Advokasi, Vol. 7, No. 1.

\section{Peraturan Perundang-Undangan}

Undang-Undang Dasar Negara Republik Indonesia Tahun 1945

Kitab Undang-Undang Hukum Acara Perdata

Undang-Undang Nomor 1 Tahun 1974 tentang Perkawinan, Lembara Negara Republik Indonesia Tahun 1974 Nomor 1

Peraturan Pemerintah Nomor 9 Tahun 1975 tentang Pelaksanaan Undang-Undang Nomor 1 Tahun 1974 tentang Perkawinan

Peraturan Daerah Propinsi Bali Nomor 3 Tahun 2001 tentang Desa Pakraman, Lembaran Daerah Provinsi Bali Tahun 2001 Nomor 29 Seri D Nomor 29. 